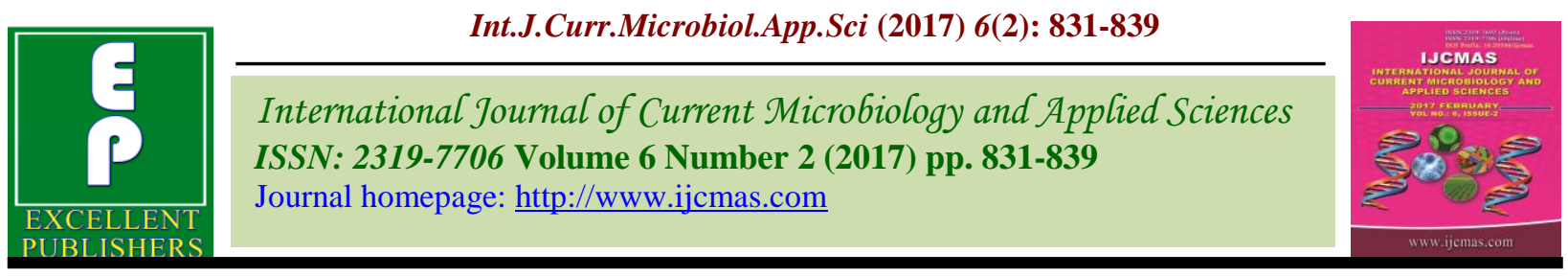

Review Article

http://dx.doi.org/10.20546/ijcmas.2017.602.093

\title{
Microbiological-Indicators with Potential for Evaluating Soil Quality
}

\author{
Sartaj Ahmad Wani ${ }^{\text {*, }}$ Muneeb Ahmad Wani', Aijaz Ahmad Sheikh ${ }^{3}$, \\ and Subhash Chand ${ }^{1}$
}
${ }^{1}$ Division of Soil Science, Sher-e-Kashmir University of Agricultural Sciences and Technology- Shalimar, Srinagar, Kashmir 190 025, India
${ }^{2}$ Division of Floriculture and Landscape Architecture, Sher-e-Kashmir University of Agricultural Sciences and Technology-Shalimar, Srinagar, Kashmir 190 025, India
${ }^{3}$ Division of Entomology, Sher-e-Kashmir University of Agricultural Sciences and Technology- Shalimar, Srinagar, Kashmir 190 025, India
*Corresponding author

\begin{tabular}{|c|c|}
\hline & A B S T R A C T \\
\hline $\begin{array}{l}\text { Activity rates, } \\
\text { Biological } \\
\text { indicators, } \\
\text { Microbial activity, } \\
\text { Microbial diversity. }\end{array}$ & \multirow{3}{*}{$\begin{array}{l}\text { An understanding of soil microorganisms as part of soil system and interactions between } \\
\text { the diversity of producers and of decomposers, have major consequences on the } \\
\text { functioning of agricultural ecosystems. Soil microorganisms control the transformation } \\
\text { and mineralization of natural compounds and xenobiotics. The soil micro biota, existing in } \\
\text { high density and diversity, rapidly modify the energetic performance and activity rates to } \\
\text { changing environmental conditions. Thus, microbial consortium possesses the ability to } \\
\text { accommodate environmental constraints by adjusting biomass, community structure and } \\
\text { activity rates. These parameters are particularly important to take into consideration when } \\
\text { evaluating soil quality. The use of microbial diversity, structure, biomass as indicators to } \\
\text { monitor soil quality is challenging due to little understanding of the relationship between } \\
\text { microbial community and soil functioning. A simple overview about the possibilities of } \\
\text { using microbial populations as quantitative indicators for soil quality evaluation is } \\
\text { presented in this paper. }\end{array}$} \\
\hline Article Info & \\
\hline $\begin{array}{l}\text { Accepted: } \\
\text { 18 January } 2017 \\
\text { Available Online: } \\
10 \text { February } 2017\end{array}$ & \\
\hline
\end{tabular}

\section{Introduction}

\section{Selection of indicators}

Soil quality is the edaphic capacity to function within ecosystem boundaries to sustain biological productivity, maintain environmental quality and promote plant and animal health (Doran et al., 1997). Soil quality (SQ) assessment has long been a challenging issue, since soils present high variability in properties and functions (Zornoza et al., 2015). Soil quality indicators are physical, chemical and biological properties or processes that can be measured to monitor changes in the soil and their effects on processes ecosystem (Brady and Weil, 2008), and the capacity to support crop production (Arshad and Martin, 2002).

Common approaches used for assessing the soil quality are either qualitative or quantitative. Qualitative indicators are often sensory descriptors (e.g. appearance, smell, feel and taste) (Dang, 2007). Quantitative indicators of soil quality involve more sophisticated analytical approaches (Harris 
and Bezdicek, 1994) and include combined and integrated analysis of the physical, chemical and biological soil properties (He et al., 2003).

The effective identification of appropriate indicators for soil quality assessment depends on the ability of any approach to consider the multiple components of a soil function for productivity in particular and environmental well being in general (Bloem et al., 2003). The selection depends on the sensitivity of these properties to soil management or changes in climate, as well as the accessibility and usefulness to producers, scientists, conservationists and policy makers (Rezaei et al., 2006, Zornoza et al., 2015). Indicators should be limited and manageable in number by different types of users, simple and easy to measure, cover the largest possible situations (Doran and Parkin, 2000) including soil types and seasonal variation and be highly sensitive to environmental changes and soil management (Dick, 2000). Thus the selection of microbiological indicators depends on the soil and functions being assessed. Since soil microorganisms can respond rapidly, they reflect a hazardous environment and therefore considered when monitoring soil status (Morugán-Coronado et al., 2013). Micro biological and biochemical indicators determine edaphic quality would be simple to measure, should work equally well in all environments and reveal, reliably, sites where problems exist. It is unlikely that a sole ideal indicator can be defined with a single measure because of the multitude of microbiological components and biochemical pathways. Therefore, a minimum data set, (MDS) is frequently applied (Sinha et al., 2009, Carter et al., 1997) for monitoring and measurement soil quality. Many countries have developed their own MDS of microbiological indicators for monitoring soil quality. In general microbial biomass and soil respiration are the most commonly used indicators. Furthermore, some of the recent tools such as Biolog, PLFA, DGGE/TGGE have been recommended for microbial diversity assessment to monitor soil quality in some countries (Winding et al., 2005, Chapman et al., 2000). In India, MDS for monitoring soil quality has been recommended but soil enzyme activities, respiration and microbial biomass are being used widely (Sharma et al., 2005, Ramesh et al., 2004).

\section{Microbial biomass}

The soil microbial biomass can be defined as organisms living in soil that are generally smaller than approximately $10 \mathrm{~mm}$. Generally, microbial biomass can offer a controlled tool in assessing the soil quality in different vegetation types (Groffman et al., 2001). Most attention is given to fungi and bacteria, being the most important to energy flow and control of major soil processes such as carbon and nutrient cycling (Milne and Haynes, 2004). Microbial biomass carbon particularly organic matter and hydrolysable carbohydrates typically comprising 1\%-5\% of the total organic matter content, are considered as biologically active fraction and are sensitive indicators of changes induced by management of soil (Lentzsch, et al., 2005). The ratio of microbial biomass $\mathrm{C}$ to soil organic $\mathrm{C}$ ( $\mathrm{C}$ mic: $\mathrm{C}$ org) reflects the contribution of microbial biomass to soil organic carbon (Anderson and Domsch, 1993). It also indicates the substrate availability to the soil microflora or, in reverse, the fraction of recalcitrant organic matter in the soil. In fact this ratio declines as the concentration of available organic matter decreases (Brookes, 1995). Microbial biomass is easily exchangeable; it is considered a sensitive indicator of alterations imposed by soil use and management (Brookes et al., 2008). The microbial biomass is a living component of soil organic matter, responds more quickly to the changes in soil conditions 
than Soil Organic matter (SOM) (Araujo et al., 2010). Soil microbial biomass is an important ecological indicator and acts as a source and sink of available nutrient for plant growth. Little change in soil microbial biomass affects directly on ecosystem stability and fertility of soil (Feng et al., 2004). Any changes in microbial biomass ultimately affect nutrient cycling of soil organic matter. Therefore, estimation of microbial biomass can provide useful information on the changes in soil biological properties (Jordan et al., 1995).

The microbial biomass estimation can be performed by several methods. The direct counting of microbial biomass in soil includes the use of staining techniques in conjunction with fluorescence microscopy or automated image analysis (Bloem and Breure, 2003). The most common indirect methods are chloroform fumigation and substrate-induced respiration (SIR) (Carter et al., 1999). Soil microbial biomass is subsequently calculated using a conversion factor (Kaiser et al., 1992).

\section{Microbial diversity}

Microbial diversity is a complex issue. Its measurement by diversity indices is usually less informative than qualitative community structure analysis. Most data suggests that community composition is more important than richness for specific microbial processes (Peter et al., 2011 Bhat, 2013). Given the central role of microbes in ecosystem processes, soil microbial facets are at least as important as the physical or chemical edaphic parameters. Even though the relationship between microbial diversity and soil functioning has not been fully unraveled (Hooper et al., 2005), these two facets should be regarded as intrinsically associated (Turbé et al., 2010). Second, microorganisms rapidly respond to environmental stresses, as they have intimate relations with their surroundings due to their high surface-tovolume ratio (Winding et al., 2005).

The term microbial community adaptation (Wallenstein and Hall, 2012) relates to how fluctuations in specific microbial populations in response to changes in environmental conditions, affect the aggregate function of the community they belong to. Due to complicity of the whole microbial community it might be useful to look at indicator organisms only, which are correlated to soil quality, for example, beneficial microbes like Rhizobium or arbuscular mycorrhiza fungi. Arbuscular mycorrhiza are the most ancient and ubiquitous root symbioses, formed by fungi belonging to the order of Glomales (Zygomycetes) and $80 \%$ of terrestrial plants (Saif and Khan, 1975, Helgason and Alastair, 2009).

The occurrence, decline and infectivity of arbuscular mycorrhiza fungi in metal-polluted soils can be used as bio-indicators of soil contamination (Ibekwe et al., 2001). Natural rhizobia populations are essential to increase the yield of leguminous crops. The importance of the interaction is based on the capacity of symbiotic Rhizobium strains to form nodules and fix atmospheric nitrogen (Zahran, 1999, Franche et al., 2009). In recent publications, soil microbial biodiversity was also shown to influence global C (Nielsen et al., 2010) and greenhouse gas budgets (Pritchard, 2011), enhance water quality, moderate soil organic matter decomposition, determine the susceptibility of soil to invasion by a pathogen (Van Elsas et. al. 2012) and regulate nutrient retention and availability (Wagg, et al., 2014).

\section{Microbial activity}

Microbial activity is the overall quantification of soil functioning, including $\mathrm{C}$ and $\mathrm{N}$ biogeochemical cycles, mainly via- soil organic matter decomposition. Microbial 
activity leads to the liberation of nutrients available for plants, but also influences the flow of $\mathrm{C}, \mathrm{N}, \mathrm{P}$, and $\mathrm{S}$ by their role in the processes of decomposition, immobilization and mineralization (Jordan et al., 2005; Marcel et al., 2008). Moreover, soil microorganisms also lead to the mineralization and mobilization of pollutants and xenobiotics (Reiger et al., 2002). Thus, microbial activity is regulated by edaphic properties such as nutritional conditions, temperature and soil water availability and are of crucial importance in nutrient biogeochemical cycling (Harris, 2009).

Microbial activity in the soil can be assessed in a number of ways. Farmers can measure the status of either the total community of microorganisms or specific members of that community. The microscopic nematodes play numerous important soil roles, with both negative and positive effects. To the soil microbial activity estimation, two groups of microbiological approaches can be distinguished. First, experiments in the field that often require long periods of incubation (Alves et al., 1993, Stenström et al., 2001) before significant changes of product concentrations are detected -- (weeks for the estimation of net $\mathrm{N}$ mineralization. In this case, variations of soil conditions during the experiment are inevitable, such as aeration, and may influence the results (Madsen, 1996). In contrast short-term laboratory procedures that are usually carried out with sieved samples at standardized temperature, water content and $\mathrm{pH}$ value (Blagodatsky et al., 2011). Such microbial activity measurements include enzymatic assays that catalyze substrate-specific transformations (Burns, 1977). This method may be helpful to ascertain effects of soil management, land use and specific environmental conditions (Burns, 1977). Taylor et al., (2002) mentioned two main reasons for measuring soil enzymes. First, as indicators of process diversity, which informs about the biochemical potential, possible resilience and potential for manipulation of the soil system-Second, as indicators of soil quality, in the sense that changes in key functions and activities can provide information about the progress of remediation operations or the sustainability of particular types of land management. Mijangos et al., (2014) observed that replacing meadows with pine plantations under a temperate climate influences enzyme activities and nutrient cycling. Moreover, enzyme activity was sensitive to humaninduced alterations in a land use sequence from natural forest pastures and shrub lands in the Andes of southern Ecuador mineral top soils of Cambisols/Umbrisols (Tischer et al., 2014). Similarly, in the reclamation of the pasture with Panicum maximum, as evidenced by improvements in the microbiological and biochemical soil health indicators, through $\mathrm{CO}_{2}$ evolution decrease, whereas microbial biomass $\mathrm{C}$ increased, resulting in a lower metabolic quotient $(q \mathrm{CO} 2)$ that points to a decrease in metabolic stress of the microbial community (Santos et al., 2015).

\section{Soil organic carbon and total nitrogen}

Soil organic carbon and total nitrogen reflecting the functional capability of soil to supply nutrients to plants, mitigate greenhouse gas accumulation, and provide organic resources for stabilizing the soil surface against erosion, filtering of water, and for promoting a biologically diverse and healthy microbial population (Brady and Weil, 2008). Soil organic matter is a key component of productivity, avoidance of synthetic inputs, healthy food supply, and environmental protection goals (Magdoff and Weil, 2004.) Soil organic matter (SOM) has been suggested as the most important single indicator of soil quality (SQ) for agricultural sustainability since it affects most soil properties (Arias et al., 2005). Consequently, 
SOM has been suggested as biological indicator of soil quality related to the sustainability of the production system (Bini, 2014, Cardoso et al., 2013, Kaschuk et al., 2010) and is more sensitive to indicate changes in soil quality (Cardoso et al., 2013).

Soil microorganisms divert more energy from growth to maintenance as stress increases and thus the ratio of respired $\mathrm{C}$ to biomass $\mathrm{C}$ can be a much more sensitive indicator of stress. The basal soil respiration / microbial biomass carbon (BSR/MBC) ratio indicates the carbon turnover rates in the soils, the importance of soil organic carbon in improving the overall soil quality (Debasish et al., 2014, Fialho and Zinn, 2014). Microorganisms indeed make up the largest part of the total biomass in the soil (Winding et al., 2005) and are key drivers in processes that contribute to the provision of essential ecosystem services, such as respiration, decomposition of organic matter and nitrification and other N-related processes (Barios, 2007). These compounds of soil are the main nutrition used for vegetation growth, and are also used as indexes of soil quality assessment and sustainable land use management (Liu et al., 2011, Jiang et al., 2007). The relationship between oil organic carbon and nitrogen represented as soil $\mathrm{C} / \mathrm{N}$ ratio, is considered a sensitive indicator of soil quality and for assessing carbon and nitrogen cycling of soils (Zhang et al., 2011). As the $\mathrm{C}$ : $\mathrm{N}$ ratio increases so $\mathrm{N}$ mineralization decreases, giving an indication of the potential activity of soil microbial populations (White, 1997). The ratio of $\mathrm{C}: \mathrm{N}$ is relatively constant in temperate agricultural soils and falls between 10-12:1 (Kalinina et al., 2010). The $\mathrm{C}$ : $\mathrm{N}$ ratio is particularly useful when looking at organic materials applied to soils; as values increase above 30 , the soil biomass becomes limited by the quantity of $\mathrm{N}$ and will not be able to utilize the $\mathrm{C}$. This reduction in available $\mathrm{N}$ is termed immobilization and can last a significant time (a growing season) depending on a range of factors, but particularly the $\mathrm{C}$ : $\mathrm{N}$ of the added residue (Rowell, 1994). Therefore, through monitoring changes etc, in total $\mathrm{N}$, an indication of potential $\mathrm{N}$ behavior in soil can determined through nitrogen fractionation, mineralization kinetics, nitrogen isotope variation etc.

In conclusion, the great abundance and diversity of microorganisms in soil have high metabolic potentials. Since microorganisms have generally limited growth in soils, they may poorly exploit their capabilities. In contrast, soil microorganisms respond rapidly to stressors by adjusting activity rates, biomass, and community structure. Combining soil microbiological estimates seems to be of great relevance for evaluating soil quality. However, an improved understanding of microbial processes, community structure and natural temporal and spatial variation is needed. Further scientific knowledge should be developed through research activities included in the monitoring programme to provide a scientific base for new management policies. A scientifically sound mathematical modeling of data followed by qualified interpretation is the tools available today for quantification to develop a base line.

\section{References}

Alves, B.L.R., Urquiaga, S., Cadisch, G., Souto, C.M., Boddy, R.M. 1993. In situ estimation of soil nitrogen mineralization. In: Mulongoy, K., Merckx, R. (Eds.), Soil Organic Matter Dynamics and Sustainability of Tropical Agriculture. Wiley-Sayce Co-Publication, IITA/K.U. Leuven, pp. 173-180.

Anderson, T.H., Domsch, K.H. 1993. The metabolic quotient for $\mathrm{CO} 2 . q \mathrm{CO} 2)$ a specific activity parameter to assess the effects of environmental conditions, such as $\mathrm{pH}$, on the microbial biomass of forest soils. Soil Biol. Biochem., 25: 393-395. 
Araujo, A.S.F., Silva, E.F.L., Nunes, L.A.P.L., Carneiro, R.F.V. 2010. Effect of converting native savanna to Eucalyptus grandis forest on soil microbial biomass in tropics. Land Degrad. Devel., 21: 540 545.

Arshad, M.A., and Martin, S. 2002. Identifying critical limits for soil quality indicators in agro-ecosystems. Agric. Ecosyst. Environ., 88: 153-160.

Barios, E. 2007. Soil biota, ecosystem services and land productivity. Ecol. Econ.,

Bhat, A.K. 2013. Preserving Microbial diversity of Soil ecosystem: A key to sustainable productivity. Int. J. Curr. Microbiol. Applied Sci., 2(8): 85-101

Bini, D. 2013. Effect of land use on soil organic carbon and microbial processes associated with soil health in southern Brazil. European J. Soil Biol., 55: 117-123.

Blagodatsky, S., Grote, R., Kiese, R., Werner, C., and Butterbach Bahl, K. 2011. Modelling of microbial carbon and nitrogen turnover in soil with special emphasis on N-trace gases emission, Plant Soil, 346: 297-330.

Bloem, J., and Breure, A.M. 2003. Microbial indicators. In: Breure AM, Markert B, Zechmeister HG. eds) Bioindicators and biomonitors. Principles, assessment, concepts, Amsterdam, Elsevier, pp. 259282.

Bloem, J., Schouten, T., Sørensen, S., Breure, A.M. 2003. Application of microbial indicators in ecological approaches to monitor soil quality. Ambio in press.

Brady, N.C. and Weil, R. 2008. The Nature and Properties of Soils. Revised 14th Edition. Pearson Prentice Hall. New Jersey. 975pp.

Brookes, P.C., Cayuela, M.L., Contin, M., De Nobili, M., Kemmitt, S.J., Mondini, C. 2008. The mineralisation of fresh and humified soil organic matter by the soil microbial biomass. Waste Manag, 28:716-722.

Brookes, P.C. 1995. The use of microbial parameters in monitoring soil pollution by heavy metals. Biol. Fert. Soils, 19: 269-
279.

Burns, R.G. 1977. Soil enzymology. Sci. Prog., 64: 275-285.

Cardoso, E.J.B.N. 2013. Soil health: looking for suitable indicators. What should be considered to assess the effects of use and management on soil health? Scientia Agricola, 70(4): 280-295.

Carter, M.R., Gregorich, E.G., Anderson, D.W., Doran, J.W., Janzen, H.H., Pierce, F.J. 1997. Concepts of soil, quality and their significance. In: Gregorich, E.G., Carter, M.R.. Eds.), Soil Quality for Crop Production and Ecosystem Health. Amsterdam, Elsevier, pp. 1-19.

Carter, M.R., Gregorich, E.G., Angers, D.A., Beare, M.H., Sparling, G.P, Wardle, D.A., Voroney, R.P. 1999. Interpretation of microbial biomass measurements for soil quality assessment in humid temperate regions. Can. J. Soil Sci., 79:507-520.

Chapman, S.J., Campbell, C.D., Edwards, A.C., McHenery, J.G. 2000. Assessment of the potential of new biotechnology environmental monitoring techniques. Report no. SR. 99) 10F, Macaulay Research and Consultancy Services, Aberdeen.

Dang, M.V. 2007. Qualitative and quantitative soil quality assessments of tea enterprises in Northern Vietnam. Afr. J. Agric. Res., 2: 455-462.

Debasish, S., Kukal, S.S., and Bawa, S.S. 2014. Soil organic carbon stock and fractions in relation 25 to land use and soil depth in the degraded Shiwaliks Hills of Lower Himalayas, Land Degrad. Dev., 25: 407416.

Dick, R. 2000. Soil enzyme stability as an ecosystem indicator. Oregon, United States: http://cfpub.epa.gov/ncer_abstracts.

Doran, J., Parkin, T. 2000. Quantitative Indicators of soil quality: A minimum data set. In: Doran J, Jones, A., editor. Methods for assessing soil quality. Wisconsin: Soil Science Society of America; Chapter 2. 
Doran, J.W., Sarrantonio, M., and Leibeg, M.A. 1997. Soil health and sustainability. In: Advances in Agronomy, Vol. 56.. D.L. Sparks, Ed.), Academic press San Deigo, CA. pp. 1-54.

Fialho, R.C. and Zinn, Y.L. 2014. Changes in soil organic carbon under eucalyptus plantations in Brazil: a comparative analysis, Land Degrad. Dev., 25: 428437.

Feng, Y., Motta, A.C., Reeves, D.W., Burmester, C.H., van Santen, E., Osborne, J.A. 2004. Soil microbial communities under conventional-till and no-till continuous cotton systems. Soil Biol. Biochem., 35: 1693-1703.

Franche, C., Lindström, K., Elmerich, C. 2009. Nitrogen-fixing bacteria associated with leguminous and non-leguminous plants. Plant Soil, 321: 35-59

Groffman, P.M., McDowell, W.H., Myers, J.C, and Merriam, J.L. 2001. Soil microbial biomass and activity in tropical riparian forests. Soil biology and Biochemi., 33:1339-1348.

Harris J. 2009. Soil Microbial Communities and Restoration Ecology: Facilitators or Followers? Sci., 325: 573-574.

Harris, R.F., Bezdicek, D.F. 1994. Descriptive aspects of soil quality/health. In: Doran JW, Coleman DC, Bezdicek DF, Stewart BA. eds) Defining soil quality for a sustainable environment. SSSA Special publication number 35, Wisconsin, pp 23-36.

Helgason, T., and Alastair, H.F. 2009. Natural selection and the evolutionary ecology of the arbuscular mycorrhizal fungi. Phylum Glomeromycota) J. Experimental Bot., 60(9): 2465-2480

He, Z.L., Yang, X.E., Baligar, V.C., Calvert, D.V. 2003. Microbiological and biochemical indexing systems for assessing quality of acid soils. $A d v$. Agron., 78: 89-138.

Hooper, D.U., Chapin, F.S., Ewel, J.J., Hector, A., Inchausti, P., Lavorel, S., Lawton, J.H. 2005. Effects of biodiversity on ecosystem functioning: a consensus of current knowledge. Ecol. Monogr., 75: 335

Ibekwe, A.M., Paiernik, S.K., Gan, J., Yates, S.R., Yang, C.H., Crowley, D. 2001. Impact of fumigants on soil microbial communities. Appl. Environ. Microbiol., 67: 3245-3257.

Jordan, D., Kremer, R.J., Bergfield, W.A, Kim, K.Y., and Cacnio, V.N. 1995. Evaluation of microbial methods as potential indicators of soil quality in historical agricultural fields. Biology Fertility and Soils, 19: 297-302.

Jordan, D., Miles, R.J., Hubbard, V.C., Lorenz, T. 2004. Effect of management practices and cropping systems on earthworm abundance and microbial activity in sanborn field: a 115-year-old agricultural field. Fresenius Environ. Bull.,48. 2): 99110.

Kaiser, E.A.., Muller, T., Jorgensen, R.G., Insam, H., Heinemeyer, O. 1992. Evaluation of methods to estimate the soil microbial biomass and the relationships with soil texture and organic matter. Soil Biol. Biochem., 24: 675-683.

Kalinina, O., Goryachkin, S.V., Karavaeva, N.A., Lyuri, D.I., and Giani, L. 2010. Dynamics of carbon pools in postagrogenic sandy soils of southern taiga of Russia, Carbon Balance and Management, 5(1).

Kaschuk, G., Alberton, O., Hungria, M. 2010. Three decades of soil microbial biomass studies in Brazilian ecosystems: Lessons learned about soil quality and indications for improving sustainability. Soil Biol. Biochem., 42: 1-13.

Liu, M., Li, Z.P., Zhang, T.L., Jiang, C.Y. and Che, Y.P. 2011. Discrepancy in Response of Rice Yield and Soil Fertility to LongTerm Chemical Fertilization and Organic Amend- ments in Paddy Soils Cultivated from Infertile Upland in Subtropical China, Agricultural Sciences in China, 10. (2): 259-266.

Madsen, E.L. 1996. A critical analysis of methods for determining the composition and biogeochemical activities of soil 
microbial communities in situ. In: Stotzky, G., Bollag, J.M. Eds.), Soil Biochemistry, vol. 9. Marcel Dekker, New York, 287-370.

Magdoff, F., Weil, R.R. 2004. Soil Organic Matter in Sustainable Agriculture. CRC Press, Boca Raton, FL. 398pp.

Marcel, G.A., van der Heijden, Richard, D., Bardgett, and Nico, M. van Straalen. 2008. The unseen majority: soil microbes as drivers of plant diversity and productivity in terrestrial ecosystems Ecol. Lett., 11: 296-310

Mijangos, I., Epelde, L., Garbisu, C., and González-Oreja, J.A. 2014. Modification of soil enzyme activities as a consequence of replacing meadows by pine plantations under temperate climate, Pedobiologia, 57: 61-66.

Milne, R.M., and Haynes, R.J. 2004. Soil organic matter, microbial properties, and aggregate stability under annual and perennial pastures. Biology and Fertility of Soil, 39: 172-178.

Morugán-Coronado, A., Arcenegui, V., GarcíaOrenes, F., Mataix-Solera, J., and MataixBeneyto, J. 2013. Application of soil quality indices to assess the status of agricultural soils irrigated with treated wastewaters, Solid Earth, 4: 119-127.

Nielsen, U.N., Ayres, E., Wall, D.H., Bardgett, R.D. 2010. Soil biodiversity and carbon cycling: A review and synthesis of studies examining diversity-function relationships. Eur. J. Soil Sci., 105-116.

Lentzsch, P., Wieland, R., Wirth, S. 2005. Application of multiple regression and neural network approaches for landscapescale assessment of soil microbial biomass. Soil Biol. Biochem., 37: 15771580.

Peter, H., Beier, S., Bertilsson, S., Lindstrom, E.S., Langenheder, S., Tranvik, L.J. 2011. Function specific response to depletion of microbial diversity. ISME J., 5: 351-361

Pritchard, S.G. 2011. Soil organisms and global climate change. Plant Pathol., 60: 82-89.

Ramesh, A., Billore, S.D., Singh, A., Joshi, O.P., Bhati, V.S,. Bundela, V.P.S. 2004.
Arylsulphatase activity and its relationship with soil properties under soybean. Glycine max) -based cropping systems. Indian J. Agric. Sci., 74: 9-13

Reiger, P.G., Meier, H,M,. Gerle, M., Vogt, U., Groth, T., Knackmuss, H.J. 2002. Xenobiotics in the environment: present and future strategies to obviate the problem of biological persistence. $J$. Biotech., 94: 101-123.

Rezaei, S., Gilkes, R., Andrews, S. 2006. A minimum data set for assessing soil quality in rangelands. Geoderma, 136: 229-34.

Rowell, D.L. 1994. Soil Science, methods and applications. Longman Scientific and Technical. Harlow.

Saif, S.R., Khan, A.G. 1975. The influence of season and stage of development of plant on endogone mycorrhiza of field-grown wheat. Can. J. Microbiol., 21: 1020-1024

Santos, C.D., Krawulski, C.C., Bini, D., Filho, T.G., Knob, A., Medina, C.C., Filho, G.A., Nogueira, M.A. 2015. Reclamation status of a degraded pasture based on soil health indicators. Scientia Agricola, 72: 195-202.

Sharma, M.P., Sharma, S.K. 2006. Arbuscular mycorrhizal fungi: an emerging bioinoculant for production of soybean. SOPA Digest, III: 10-16

Sinha, S., Masto, R.E., Ram, L.C., Selvi, V.A., Srivastava, N.K., Tripathi, R.C., and George, J. 2009. Rhizosphere soil microbial index of tree species in a coal mining ecosystem, Soil Biol. Biochem., 41:1824-1832.

Stenström, J., Svensson, K., and Johansson, M. 2001. Reversible transition between active and dormant microbial states in soil. FEMS Microbiol. Ecol.,36: 93-104.

Taylor, J.P., Wilson, M., Mills, S., Burns, R.G. 2002. Comparison of microbial numbers and enzymatic activities in surface soils and subsoils using various techniques. Soil Biol. Biochem., 34: 387-401.

Tischer, A., Blagodatskaya, E., and Hamer, U. 2014. Extracellular enzyme activities in a tropical mountain rainforest region of 
southern Ecuador affected by low soil $\mathrm{P}$ status and land-use change, Appl. Soil Ecol., 74: 1-11.

Turbé, A., De Toni, A., Benito, P., Lavelle, P., Lavelle, P, Ruiz N, Van der Putten WH, Labouze, E, Mudgal S. 2010. Soil Biodiversity: Functions, Threats and Tools for Policy Makers. Bio Intelligence Service, IRD, and NIOO, Report for European Commission DG Environment.

Van Elsas, J.D., Chiurazzi, M., Mallon, C.A., Elhottova, D., Kristufek, V., Salles, J.F. 2012. Microbial diversity determines the invasion of soil by a bacterial pathogen. Proc. Natl. Acad. Sci. USA, 109: 11591164.

Wagg, C., Bender, S.F., Widmer, F., van der Heijden, M.G.A. 2014. Soil biodiversity and soil community composition determine ecosystem multifunctionality. Proc. Natl. Acad. Sci. USA, 111: 52665270.

Wallenstein, M.D., Hall, E.K. 2012. A traitbased framework for predicting when and where microbial adaptation to climate change will affect ecosystem functioning. Biogeochem., 109: 35-47

White, R.E. 1999. Principles and Practice of Soil Science, the Soil as a Natural
Resource, 3rd Edition. Blackwell Science Ltd, Oxford.

Winding, A., Hund-Rinke, K., Rutgers, M. 2005. The use of microorganisms in ecological soil classification and assessment concepts. Ecotoxicol. Environ. Saf., 62: 230-268.

Jiang, Y., Zhuang, Q.L., and Liang, W.J. 2007. Soil Organic Carbon Pool and Its Affecting Factors in Farm Land Ecosystem, Chinese J. Ecol., 26. 2): 278-285.

Zahran, H.H. 1999. Rhizobium-Legume Symbiosis and Nitrogen Fixation under Severe Conditions and in an Arid Climate Microbiol. Mol. Biol. Rev., 63(4): 968989.

Zhang, C.H., Wang, Z.M., Ju, W.M., and Ren, C.Y. 2011. Spatial and Temporal Variability of Soil C/N Ratio in Songnen Plain Maize Belt. Environ. Sci., 32(5): 1407-1414.

Zornoza, R., Acosta, J.A., Bastida, F., Domínguez, S.G., Toledo, D.M., and Faz, A. 2015. Identification of sensitive indicators to assess the interrelationship between soil quality, management practices and human health. Soil, 1: 173185.

\section{How to cite this article:}

Sartaj, Ahmad Wani, Muneeb Ahmad Wani, Aijaz Ahmad Sheikh and Subhash Chand. 2017. Microbiological-Indicators with Potential for Evaluating Soil Quality. Int.J.Curr.Microbiol.App.Sci. 6(2): 831-839. doi: http://dx.doi.org/10.20546/ijcmas.2017.602.093 